
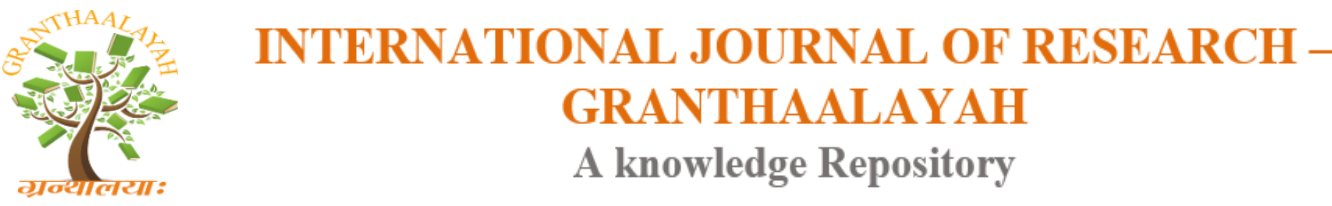

Science

\title{
PROMOTION OF STUDENTS FOR ENVIRONMENT FRIENDLY TREE PLANTATION
}

\author{
Dr. Paras Jain *1, Soman Malaiya ${ }^{2}$ \\ ${ }^{* 1}$ Director, Silicobyte Katni Degree College, Dikshabhumi Campus, Adharkap, Katni (M.P) - \\ 483501, India \\ ${ }^{2}$ Soman Malaiya, Vice Principal, Silicobyte Katni Degree College, Dikshabhumi Campus, \\ Adharkap, Katni (M.P) -483501, India
}

\begin{abstract}
Plantation is best way to save environment. Awareness in this connection is important and efforts required creating in mass. Focus of students for promotion of plantation is needed to make regular activity of school. Present study is focused on finding of ways to promote tree plantation and impact of such way on students.
\end{abstract}

Keywords: Plantation; Awareness; Population; Ambassadors.

Cite This Article: Dr. Paras Jain, and Soman Malaiya. (2017). "PROMOTION OF STUDENTS FOR ENVIRONMENT FRIENDLY TREE PLANTATION.” International Journal of Research - Granthaalayah, 5(7), 584-586. https://doi.org/10.29121/granthaalayah.v5.i7.2017.2165.

\section{Introduction}

The benefits of trees are unlimited. They are strongest shield against harms of air pollution. They strengthen soil, resist natural calamities especially floods, provide shadow, lessen the heat of temperature, muffle noise, enhance beauty of surrounding, give fruits, herbs and vegetables. They protect waterways by interacting storm water; improve air quality by absorbing some airborne compounds which are harmful and by giving off oxygen.

Planned plantation is necessary to get expected result. Unplanned development is not letting us to plant trees. Buildings, bridges, roads, highways, airports, factories, monuments and several such things are being constructed everywhere. Population is rising so people can't strive on natural resources and they transformed into artificial abundance and converted into artificial resources for short live benefits.

For promotion of students for tree plantation, a task of students should be made. They may be asked to fill undertaking to plant at least one tree every year. They should be convinced to give sapling as gift to each other. Students should be motivated to plant trees at their homes, school and places where they sit together. Plantation looks appealing in news and in official files but on 
ground it fails to bring desired results because of non involvement of communities into it. No grass root level campaign get success without community participation. Students should be made care taker of plants. A tree plantation festival can also be arranged. The culture of sitting under trees should be promoted to make people habitual of them. Slogan writing, essay writing, quiz competition, drawing competition should be organized to bring awareness.

\section{Objective of Study}

To find impact of different ways of promotion of students for plantation

\section{Hypothesis}

There is no significant impact of different ways of promotion of students for plantation

\section{Methodology}

1000 students of class 6-12 were taken as sample. It was consists of 500 male and 500 female students. Sample was tested for their interest towards plantation and data was collected. They have promoted for planned plantation using different ways and again tested for interest in plantation. Collected data was tabulated and comparatively analyzed using mean, standard deviation and t value statistical tool.

\section{Finding and Analysis}

Table 1: Comparative Status of Students without Promoted and Promoted For Tree Plantation

\begin{tabular}{|c|c|c|c|c|c|}
\hline \multirow{2}{*}{$\begin{array}{l}\text { Components of } \\
\text { Promotion }\end{array}$} & \multicolumn{2}{|c|}{$\begin{array}{c}\text { Student Interest without } \\
\text { Promotional Activity for } \\
\text { Plantation }\end{array}$} & \multicolumn{2}{|c|}{$\begin{array}{c}\text { Student Interest After } \\
\text { Promotional Activity for } \\
\text { Plantation }\end{array}$} & \multirow{2}{*}{ t value } \\
\hline & Mean Value & $\begin{array}{l}\text { Standard } \\
\text { Deviation }\end{array}$ & Mean Value & $\begin{array}{l}\text { Standard } \\
\text { Deviation }\end{array}$ & \\
\hline $\begin{array}{l}\text { Oral } \\
\text { Presentation }\end{array}$ & 32.6 & 0.97 & 43.7 & 0.67 & 0.78 \\
\hline $\begin{array}{l}\text { Multimedia } \\
\text { Presentation }\end{array}$ & 32.6 & 0.97 & 48.4 & 1.28 & 0.91 \\
\hline $\begin{array}{l}\text { Live } \\
\text { Demonstration }\end{array}$ & 32.6 & 0.97 & 56.8 & 0.84 & 0.82 \\
\hline Poster Creation & 32.6 & 0.97 & 46.4 & 1.36 & 0.94 \\
\hline Slogan, essay & 32.6 & 0.97 & 45.2 & 1.25 & 0.91 \\
\hline Quiz & 32.6 & 0.97 & 47.2 & 0.88 & 0.89 \\
\hline
\end{tabular}




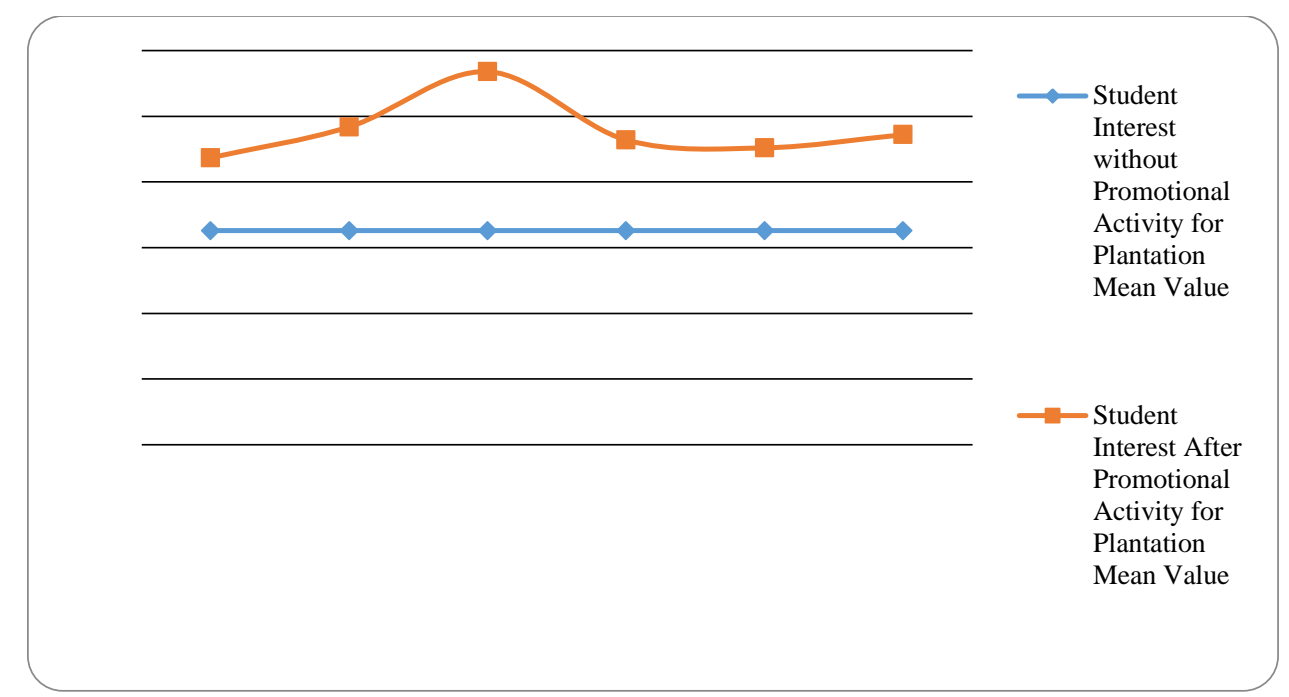

Chart 1: Comparative Status of Students without Promoted and Promoted For Tree Plantation

Data shows in condition of without promotional activity, student interest value observed 32.6 at standard deviation 0.97. Student interest value due to oral presentation reached 43.7 with standard deviation 0.67. $\mathrm{t}$ value calculated as 0.78 which is significant at 0.05 level. Multimedia presentation increased interest value 48.4 with standard deviation 1.28 and $\mathrm{t}$ value 0.91 significant at 0.05 level. Live demonstration showed mean value 56.8 at standard deviation 0.84 and $t$ value 0.82 significant at 0.05 level. Poster creation exhibits student's interest 46.4 with standard deviation 1.36 and $\mathrm{t}$ value 0.94. For slogan, essay writing student interest value observed 45.2 mean value at standard deviation 1.25 and t value 0.91 . Environment related quiz enhanced interest mean value 47.2 at standard deviation 0.88 and t value 0.89 . Hence, there is no significant impact of different ways of promotion of students for plantation is rejected.

\section{Conclusion}

Students may work as ambassadors to bring awareness for environment friendly plantation. Student's awareness about plantation is necessary to play a vital role in protecting the environment. There are many ways to promote plantation and is hoped that the experience will help them to make intelligent decisions about conservation and use of valuable natural resources. Schools must commit to watering their new trees for minimum of 2 years of planting. Student's awareness regarding importance of plants is necessary for maintaining bio diversity to save earth.

\section{References}

[1] www.pollutionpollution.com

[2] www.thehindu.com>article14489106

[3] www.cityofvancouver.us

[4] www.sspmdayschool.org

\footnotetext{
*Corresponding author.

E-mail address: parasjainkatni@gmail.com
} 